\title{
PENGKONSTRUKSIAN BIDIRECTED OVERLAP GRAPH UNTUK PERAKITAN SEKUENS DNA
}

\author{
Wisnu Ananta Kusuma* ${ }^{* 1}$, Albert Adrianus ${ }^{2}$ \\ 1,2 Departemen Ilmu Komputer, Fakultas Matematika dan Ilmu Pengetahuan Alam, Institut Pertanian Bogor \\ Email: ${ }^{1}$ ananta@apps.ipb.ac.id, ${ }^{2}$ albertadrianus@gmail.com \\ *Penulis Korespondensi
}

(Naskah masuk: 01 Juni 2019, diterima untuk diterbitkan: 11 Februari 2020)

\begin{abstract}
Abstrak
De novo DNA (Deoxyribonucleic Acid) sequence assembly atau perakitan sekuens DNA secara De novo adalah tahapan yang sangat penting dalam analisis sekuens DNA. Tahapan ini diperlukan untuk merakit atau menyambungkan kembali fragmen-fragmen DNA (reads) yang dihasilkan oleh Next Generation Sequencer menjadi genom yang utuh. Masalah perakitan DNA ini dapat direpresentasikan sebagai masalah Shortest Common Superstring (SCS). Perakitan ini memerlukan bantuan perangkat lunak untuk mendeteksi daerah yang sama pada reads DNA (overlap), mengkonstruksi overlap graph, dan kemudian mencari shortest path dari graf yang terbentuk. Metode ini dinamakan Overlap Layout Consensus (OLC). Hal terpenting dalam metode OLC adalah pendeteksian overlap dari masing-masing reads. Pada penelitian ini dikembangkan suatu teknik untuk membuat bidirected overlap graph. Suffix array digunakan untuk menentukan bagian overlap dari setiap reads dengan melakukan pengindeksan setiap suffix dari reads. Proses perakitan sekuens DNA merupakan suatu proses komputasi yang intensif. Untuk mengefisiensikan proses dilakukan perubahan masing-masing suffix dan prefix menjadi suatu nilai tertentu yang bersifat tunggal dan mencari overlap dengan membandingkan nilai yang merupakan representasi dari setiap reads. Cara ini lebih efisien dibandingkan melakukan pendeteksian overlap dengan metode pencocokan string. Hasil perbandingan menunjukkan bahwa waktu yang diperlukan untuk mengeksekusi metode yang diusulkan (perbandingan nilai) jauh lebih singkat dibandingkan dengan menggunakan metode pencocokan string. Untuk jumlah reads 2000 dan 5000 reads, teknik yang diusulkan ini dapat merepresentasikan semua reads menjadi overlap graph, di mana semua reads dapat direpresentasikan ke dalam node dan semua overlap dapat direpresentasikan ke dalam edge.
\end{abstract}

Kata kunci: Bidirected overlap graph, DNA assembly, Overlap Layout Consensus, Shortest Commong Superstring Problem

\section{BIDIRECTED OVERLAP GRAPH FOR DNA SEQUENCE ASSEMBLY (OVERLAP LAYOUT CONSENSUS)}

\begin{abstract}
De novo DNA sequence assembly is the important step in DNA sequence analysis. This step is required for assembling fragments or reads produced by Next Generation Sequencer to yield a whole genome. The problem of DNA assembly could be represented as the Shortest Common Superstring (SCS) problem. The assembly requires a software for detecting the overlap region among reads, constructing an overlap graph, and finding the shortest path from the overlap graph.. This method is popular as The Overlap Layout Consensus (OLC). The most important step in OLC is detecting overlaps among reads. This study developed a new approach to construct bidirected overlap graph. Suffis array was used for detecting overlap region from each reads by indexing suffix of each reads. DNA assembly process is computational intensive. To reduce the execution time, suffix and prefix was converted into the single value so that the detection of overlap could be done by comparing the values. This method is much more efficient compared to that of using string matching. With 5000 and 10000 reads, the proposed method (value comparison) could yield the perfect overlap graph, in which almost all reads and overlap could be represented as nodes and edges, respectively.
\end{abstract}

Keywords: Bidirected overlap graph, DNA assembly, Overlap Layout Consensus, Shortest Commong Superstring Problem 


\section{PENDAHULUAN}

Teknologi DNA perakitan sekuens DNA (DNA sequence assembly) telah berkembang pesat dan mempunyai peran penting dalam analisis genom. Teknik perakitan sekuens DNA muncul karena hingga saat ini belum ada teknologi yang dapat membaca seluruh genom (DNA) suatu organisme dalam satu kali sequencing. Sebelumnya teknologi yang digunakan untuk membaca sekuens DNA adalah teknologi Sanger sequencing. Dengan menggunakan teknologi Sanger sequencing, dihasilkan potongan-potongan reads dengan panjang 1000-2000 bp namun membutuhkan waktu yang lama dan biaya yang besar (Kae, 2003) (Pop, 2009).

Seiring berjalannya waktu, ditemukan suatu teknologi baru yaitu high throughput sequencing technologies (Zhou, 2010). Dengan teknologi tersebut, genom bakteri dimungkinkan untuk dapat dibaca hanya dalam satu eksperimen dan dengan biaya yang tidak mahal (Brenner et al., 2000). Hasil dari penguraian ini berupa jutaan potongan reads dengan panjang 35-50 bp. Potongan reads ini selanjutnya disambungkan dengan reads lain menjadi potongan-potongan yang lebih panjang (contigs), sebelum akhirnya dengan mekanisme layout dan consensus dihasilkan genom utuh (whole genome). Pendekatan ini memerlukan metode untuk menyambung atau merakit (assemble) reads yang ada.

Probrem perakitan kembali reads menjadi contigs sampai akhirnya diperoleh genom utuh ini dapat diformulasikan sebagai problem Shortest Common Superstring. Perumusan problem ini berdasarkan asumsi bahwa setiap reads harus ada di dalam genom aslinya. Hal ini karena reads pada dasarnya diperoleh dengan melakukan sequencing atau pembacaan secara acak dari genom yang utuh dengan menggunakan sequencer sehingga dihasilkan potongan-potongan fragmen yang saling overlap yang disebut reads. Dengan demikian, jika akan direkonstruksi kembali genom yang tersebut, maka dapat diperoleh dari shortest sequence atau string yang mengandung semua reads sebagai substringnya (Medvedev, 2007) (Gambar 1).

Secara garis besar metode yang umum digunakan untuk melakukan perakitan kembali reads ada dua yaitu metode Overlap Layout Consensus (OLC) dan dengan menggunakan graf De Bruijn (Kusuma et al., 2011) (Simpson and Pop, 2015). Meskipun demikian ada juga peneliti yang menggunakan pendekatan probalistik sebagai alternatif, seperti pada GAML (Boza, 2014) Pendekatan OLC adalah pendekatan yang intuitif di mana problem perakitan sekuens ini direprentasikan menjadi overlap graph. Pada overlap graph ini node merepresentasikan reads dan edge merepresentasikan overlap antar reads (Gambar 2). Pembentukan overlap graph ini adalah tahap terpenting dalam proses perakitan sekuens DNA.

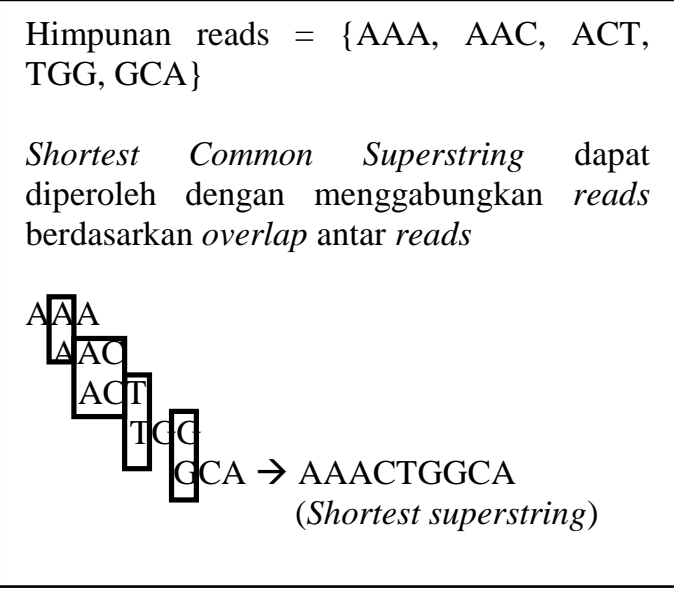

Gambar 1 Ilustrasi Problem Shortest Common Superstring

reads $=\{\mathrm{ATT}, \mathrm{CCA}, \mathrm{CAG}, \mathrm{TCC}, \mathrm{AGT}, \mathrm{GAT}\}$

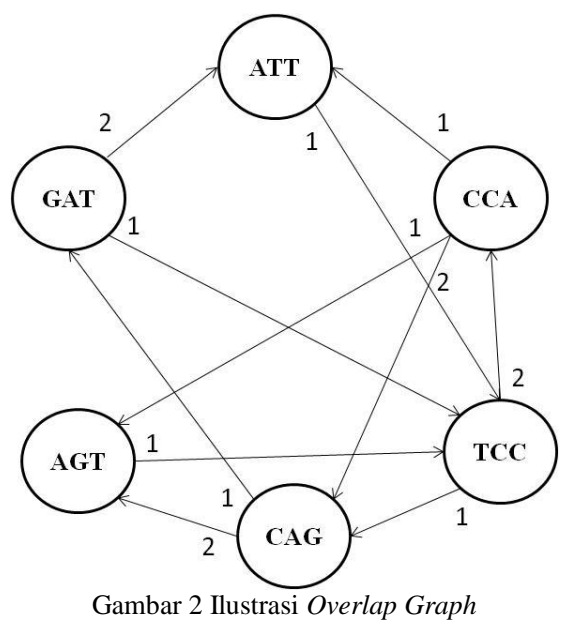

Sampai saat ini, pengembangan perangkat lunak untuk melakukan perakitan reads terus dilakukan. Beberapa perangkat yang menggunakan metode OLC untuk merakit reads tersebut antara lain Celera (Myers, 2000), ARACHNE (Batzouglou, 2002), PCAP (Huang, 2003), Phusion (Mullikin, 2003), dan EDENA (Hernandez et al., 2008). Adapun contoh yang dibangun berdasarkan pendekatan De Bruijn Graph adalah Velvet (Zerbino, 2008), SOAPDenovo (Li et. al., 2009), dan SPAdes (Bankevich et. al., 2012).

Pada EDENA, data input yang berupa potongan-potongan short reads akan diproses menjadi output yang berupa potongan-potongan contigs serta jumlah node dan edge yang terbentuk dari proses-proses yang digunakan di dalam metode OLC. Proses-proses tersebut terdiri atas proses penghilangan data reads yang redundan, pembuatan bidirected overlap graph, penghilangan transitive edges, serta pembersihan graph (Hernandez et al., 2008). Semua proses tersebut harus dilakukan secara berurutan.

Dari semua proses atau tahapan tersebut, proses yang paling penting adalah pembuatan bidirected overlap graph. Proses ini digunakan untuk mendeteksi overlap dari masing-masing reads. Jika 
mekanisme pengkonstruksian bidirected overlap graph dapat disederhanakan, maka proses perakitan DNA secara keseluruhan akan menjadi lebih efisien. Hal ini karena kompleksitas dari proses perakitan DNA dengan metode OLC ini dipengaruhi secara signifikan oleh kompleksitas saat dilakukannya pengkonstruksian bidirected overlap graph, khususnya saat pendeteksian overlap antar reads

Pada umumnya proses pendeteksian overlap antar reads untuk mengkonstruksi overlap graph dilakukan dengan algoritme string matching atau pencocokan string dalam hal ini adalah reads, seperti yang dilakukan pada Edena dengan menggunakan prefix tree (Hernandez et al., 2008). Cara lain adalah dengan menggunakan suffix array.

Pada penelitian ini algoritme pencocokan string dimodifikasi dengan menkonversikan tiap basa DNA yang dalam hal ini direpresentasikan sebagai satu karakter A, T, G, atau C ke dalam suatu nilai atau nilai. Dengan demikian proses pendeteksian overlap tidak dilakukan dengan melakukan pencocokan string tapi dengan membandingkan nilai atau nilai yang merepresentasikan basa DNA.

Input yang digunakan adalah potonganpotongan reads dengan panjang yang sama dan output yang dihasilkan adalah jumlah node dan edge yang dihasilkan dari proses yang ada. Hasil dari pendekatan menggunakan perbandingan nilai dibandingkan dengan pendekatan pencocokan string yang telah umum digunakan oleh peneliti-peneliti sebumnya.

\section{METODOLOGI}

\section{Data}

Data yang digunakan merupakan potonganpotongan reads dengan panjang 35 base pairs (bp) yang dibangkitkan menggunakan perangkat lunak simulasi sequencing, yaitu MetaSim (Richter et al., 2008). Reads dari DNA dapat direpresentasikan sebagai string yang terdiri atas empat karakter A, C, $\mathrm{G}$, dan T. Tiap karakter mewakili basa-basa nitrogen, yaitu A untuk Adenine, $\mathrm{C}$ untuk Cytosine, $\mathrm{G}$ untuk Guanine dan T mewakili Thymine. Reads ini disimpan dalam file dengan format FASTA. Contoh formal FASTA dapat dilihat pada Gambar 3.

Data yang diperlukan merupakan data yang tidak mengandung redundansi dan bebas dari sequencing error. Informasi selengkapnya mengenai data reads yang digunakan pada penelitian ini dapat dilihat pada Tabel 1 .

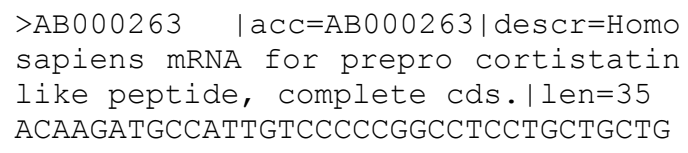

Gambar 3 Contoh Reads dengan Format FASTA

Pada penelitian ini digunakan dua data DNA, yaitu yang berasal dari Acidiphilium multivorum
AIU301 plasmid pACMV4, yang memiliki panjang total sekitar 40.6 Kilo basepair (Kbp) dan Saccharomyces cerevisiae EC1118 chromosome V, yang memiliki panjang total genomnya sekitar $12 \mathrm{Mbp}$. Keduanya dipilih agar data DNA yang digunakan merepresentasikan ukuran genom yang pendek dan panjang.

Untuk genom dengan ukuran yang pendek, yaitu Acidiphilium multivorum AIU301 plasmid pACMV4, dibangkitkan reads dengan menggunakan perangkat lunak simulasi sequencer Metasim dengan jumlah reads 2000, 5000, dan 10000. Adapun untuk Saccharomyces cerevisiae EC1118 chromosome V karena ukurannya jauh lebih panjang, maka jumlah reads yang dibangkitkan lebih banyak, yaitu 5000 dan 1000. Hal ini dilakukan agar jumlah reads yang dibangkitkan memiliki coverage yang memadai untuk membentuk bidirected overlap graph.

\begin{tabular}{|c|c|c|c|}
\hline No & $\begin{array}{l}\text { Sekuens DNA } \\
\text { (Organisme) }\end{array}$ & $\begin{array}{l}\text { Panjang } \\
\text { Genom }\end{array}$ & $\begin{array}{l}\text { Jumlah } \\
\text { Reads }\end{array}$ \\
\hline 1. & $\begin{array}{l}\text { Acidiphilium } \\
\text { multivorum } \\
\text { AIU301 plasmid } \\
\text { pACMV4 }\end{array}$ & $40.6 \mathrm{Kbp}$ & $\begin{array}{l}2000, \\
5000 \text { dan } \\
10000\end{array}$ \\
\hline 2 & $\begin{array}{l}\text { Saccharomyces } \\
\text { cerevisiae EC } 1118 \\
\text { chromosome V }\end{array}$ & $12 \mathrm{Mbp}$ & $\begin{array}{l}5000 \\
\text { dan } \\
10000\end{array}$ \\
\hline
\end{tabular}

Dalam simulasi menggunakan MetaSim, digunakan error model dengan pilihan exact. Hal tersebut dilakukan agar data yang dihasilkan nantinya merupakan data yang bebas kesalahan (error free). Data yang error free berarti dismulasikan tidak ada kesalahan pembacaan oleh sequencer. Dengan demikian akan dihasilkan reads di mana urutan basa nitrogennya sama dengan organism aslinya. Hasil simulasi dari perangkat MetaSim masih memungkinkan memiliki data yang redundan. Data redundan yang dimaksud adalah adanya read yang sama persis satu dengan yang lain, mengingat reads dibangkitkan secara acak. Pada penelitian ini dilakukan praproses dengan menghilangkan data yang redundan. Hal tersebut diperlukan agar graf yang terbentuk tidak kompleks. Selain itu juga dilakukan pembuatan reverse complement dari setiap reads. Hal ini disebabkan proses sequencing dilakukan dari dua sesuai dengan karakteristik struktur DNA yang berbentuk double helix.

\section{Metode}

Penelitian terdiri atas beberapa tahap antara lain pembacaan reads dan pembuatan reverse complement, pengindeksan dengan menggunakan suffix array, pencarian overlap antar reads dan reverse complement, serta perhitungan node dan edge sebagai hasil keluaran dari sistem. Tahapan atau proses yang dilakukan oleh perangkat lunak pengkonstruksi bidirected overlap graph secara ringkas dapat dilihat pada Gambar 4. 


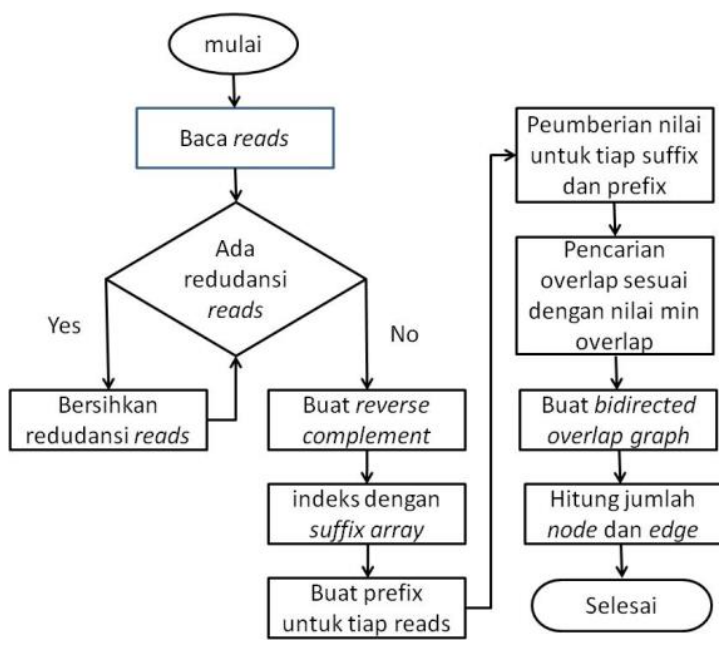

Gambar 4 Tahapan Pembentukan Bidirected Graph

\section{Pembacaan input reads}

Pertama-tama sistem akan membaca data masukan yang berupa potongan-potongan reads hasil simulasi dari software MetaSim. Data yang akan dibaca oleh sistem hanyalah data input yang merupakan potogan dari DNA, sedangkan data yang berupa keterangan atau header tidak dibaca oleh sistem. Jika dilihat dari Gambar 1, data yang digunakan adalah data yang memuat informasi DNA atau basa atau nukleotida, sebagai berikut ACAAGATGCCATTGTCCCCCGGCCTCCTGCTGCTG .

Potongan-potongan reads tersebut mempunyai panjang 35 bp (base pair). Data yang digunakan sebanyak 2000 dan 5000 buah.

\section{Pembersihan input reads redundan}

Reads yang telah dibaca oleh sistem akan diperiksa satu persatu. Apabila ada reads identik yang berjumlah lebih dari satu maka sistem hanya akan mengambil salah satu read. Hal ini agar data input yang akan digunakan untuk proses selanjutnya bebas dari data yang redundan. Data yang bebas redundan tersebut kemudian akan dimasukan ke dalam sebuah vector untuk digunakan pada proses selanjutnya.

\section{Pembuatan reverse complement}

Setelah itu sistem akan membuat reverse complement dari masing-masing read yang menjadi masukan. Reverse complement itu sendiri merupakan reads yang isinya ditukar menurut pasangan basa nitrogennya (A menjadi T, C menjadi G, G menjadi C, dan T menjadi A) dan setelah itu urutan dari basa-basa nitrogen tersebut diurutkan terbalik. Hal ini dikarenakan high throughput sequencing technologies menguraikan DNA dari 2 sisi, dari sisi kiri dan sisi kanan. Karena itu, hasil potongan-potongan reads tidak diketahui apakah merupakan potongan dari rantai primer atau merupakan bagian dari rantai sekunder.

\section{Penentuan jumlah minimum overlap}

Poin penting dalam penelitian ini adalah jumlah minimum overlap, karena akan menentukan banyaknya jumlah reads overlap satu sama lain (node) dan jumlah overlap secara keseluruhan (edge). Hal ini juga dikarenakan apabila jumlah minimum overlap terlalu sedikit akan membuat graph yang dibentuk menjadi semakin kompleks. Graph yang terbentuk semakin kompleks karena semakin kecil jumlah minimum overlap maka jumlah read yang saling overlap satu sama lain akan semakin banyak. Hal tersebut akan membuat jumlah node dan edge yang dihasilkan akan semakin banyak. Adapun jika jumlah minimum overlap terlalu besar, maka akan menyebabkan semakin sedikit reads yang saling overlap. Hal tersebut akan menyebabkan terjadinya dead end path pada graph ketika proses penyambungan kumpulan reads yang saling overlap. Karena jumlah minimum overlap menjadi penting maka selanjutnya sistem akan meminta jumlah minimum overlap yang diharapkan oleh user.

Jumlah minimum overlap yang digunakan dalam rentang 20 sampai 30. Apabila jumlah yang dimasukan user tidak dalam rentang tersebut maka sistem akan meminta user untuk memasukkan nilai lagi sampai nilai masukan user berada dalam rentang yang telah ditetapkan.

\section{Pengindeksan dengan suffix array}

Tahap selanjutnya yaitu masing-masing reads akan diindeks dengan menggunakan suffix array. Suffix array merupakan perkembangan dari suffix tree. Suffix array adalah sebuah list terurut dari semua suffix suatu kata (Manber dan Myers 1993).

Misalkan terdapat sebuah string "abracadabra". Hal pertama yang akan dilakukan adalah proses pemasangan indeks ke masing-masing karakter dari string tersebut. Sebagai contoh pada string "abracadabra", a akan diberi indeks 1, b diberi indeks $2, \mathrm{r}$ diberi indeks 3 , a diberi indeks 4 , c diberi indeks 5 , a diberi indeks 6 , d diberi indeks 7, a diberi indeks $8, \mathrm{~b}$ diberi indeks $9, \mathrm{r}$ diberi indeks 10 , dan a diberi indeks 11. Setelah pemasangan indeks terhadap masing-masing karakter dari string tersebut kemudian dibuat suffix dari string tersebut sesuai dengan indeks yang diberikan. Dalam kasus dengan string "abracadabra" maka akan terdapat 11 suffix sesuai indeks yang ada yaitu "abracadabra", "bracadabra", "racadabra", “acadabra", "cadabra", "adabra", "dabra", “abra", "bra”, "ra”, dan "a". Untuk lebih jelasnya dapat dilihat pada Gambar 5.

Setelah didapatkan indeks seperti di atas maka kemudian akan diurutkan secara lexicographical atau berdasarkan abjad seperti pada Tabel 2 .

Karena itu suffix array untuk string "abracadabra" adalah $\{107035814692\}$. Pada penelitian ini, suffix array digunakan untuk mendata overlap dari masing-masing reads menurut nilai jumlah minimum overlap yang telah ditetapkan oleh 
user sebelumnya. Bagian suffix yang tidak memenuhi jumlah minimum overlap akan langsung dihilangkan agar tidak terproses ke tahap selanjutnya. Selain itu dilakukan juga hal yang sama pada setiap reverse complement dari masing-masing read. Pada tahap yang sama juga dilakukan pengindeksan prefix dari masing-masing reads dan reverse complement yang ada. Sehingga pada akhirnya didapat prefix dan suffix dari masingmasing reads dan reverse complement untuk diproses pada tahap selanjutnya

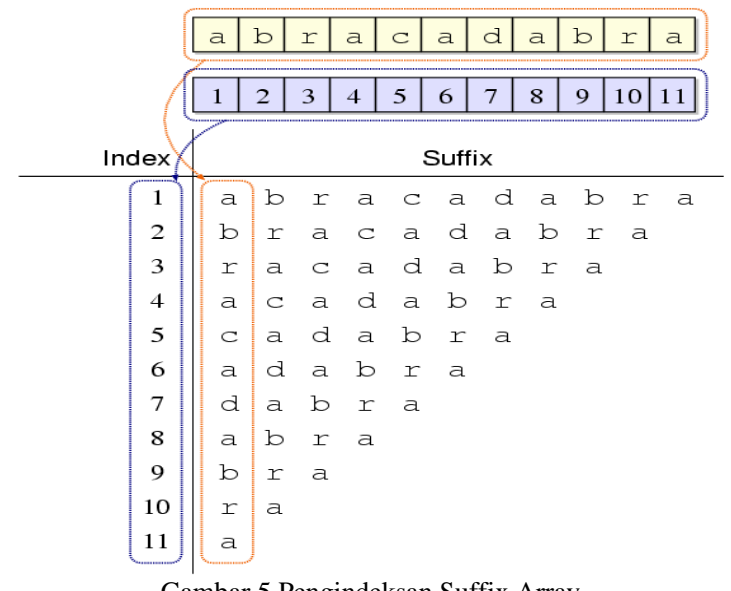

Gambar 5 Pengindeksan Suffix Array

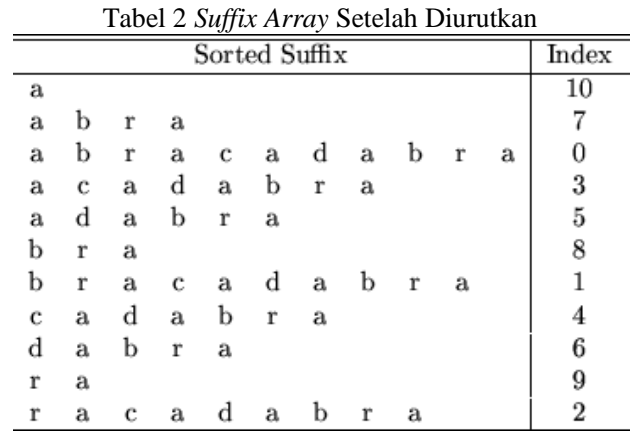

\section{Pembuatan prefix}

Pada tahap ini akan dicari prefix dari setiap read dan reverse complement yang ada. Prefix yang dicari juga mempunyai ketentuan tertentu. Prefix akan didata apabila memiliki jumlah karakter lebih besar dari jumlah minimum overlap yang dimasukan oleh user sebelumnya. Proses yang dilakukan sebenarnya sama dengan proses pencarian suffix, namun demikian bedanya pada tahap ini yang dicari adalah bagian prefix.

\section{Pemberian nilai pada suffix dan prefix}

Setelah masing-masing reads dan reverse complement telah memiliki prefix dan suffix, setiap prefix dan suffix tersebut diubah menjadi nilai. Adapun pengubahan ini dilakukan untuk membuat waktu yang dibutuhkan pada proses selanjutnya menjadi lebih singkat. Proses pengubahan dari string menjadi double dilakukan dengan ketetapan tertentu. Aturan pertama adalah dengan cara membuat nilai tertentu bagi masing-masing huruf dari basa nitrogen yang ada. Penentuan nilai bagi masing-masing basa nitrogen dapat dilihat pada Tabel 3.

\begin{tabular}{|c|c|}
\hline Basa Nitrogen & Nilai \\
\hline A & 1.000000 \\
\hline $\mathrm{T}$ & 0.110000 \\
\hline G & 0.111100 \\
\hline $\mathrm{C}$ & 0.111111 \\
\hline
\end{tabular}

Setelah itu dari masing-masing nilai dari huruf basa nitrogen yang ada dikalikan dengan posisinya dan dengan suatu nilai tertentu. Lalu semua nilai tersebut dijumlahkan hingga menjadi sebuah nilai tunggal yang merepresentasikan suffix dan prefix dari masing-masing reads dan reverse complement yang ada (aturan pertama). Nilai hasil tersebut memungkinkan adanya suatu collision yang yaitu keadaan di mana ada dua suffix/prefix yang memiliki nilai yang sama namun bentuk fisik yang berbeda, karena itulah diperlukan nilai kedua yaitu nilai jumlah karakter suatu suffix/prefix (aturan kedua). Nilai suatu suffix/prefix (nilai suatu overlap) dapat dicari dengan formula seperti dit.unjukkan pada Persamaan 1-4 berikut

Basa nitrogen "A" :

Nilai suatu suffix/prefix $=\sum_{i=1}^{\max } i \bullet a \bullet 0.11$

Basa nitrogen " $T$ "

Nilai suatu suffix/prefix $=\sum_{i=1}^{\text {maks }} i \bullet a \bullet 0.1111$

Basa nitrogen " $G$ " :

Nilai suatu suffix/prefix $=\sum_{i=1}^{m a k s} i \bullet a \bullet 0.111111$

Basa nitrogen " $C$ " :

Nilai suatu suffix/prefix $=$

$\sum_{i=1}^{m a k s} i \bullet a \bullet 0.11111111$

Keterangan :

$i \quad$ : posisi suatu variabel

a : nilai variabel pada posisi $i$

max : jumlah maksimal variabel suatu suffix atau prefix

Aturan kedua digunakan untuk mengetahui jumlah tiap basa nitrogen pada masing-masing suffix dan prefix. Pencarian nilai tiap jenis basa nitrogen berbeda. Setiap basa nitrogen "A" akan menambah nilai sebesar 1, basa nitrogen " $T$ " akan menambah nilai jumlah karakter suffix/prefix sebelumnya sebesar 0.11 , basa nitrogen "G" akan menambah nilai jumlah karakter suffix/prefix sebelumnya sebesar 0.1111, dan basa nitrogen "C" akan 
menambah nilai jumlah karakter suffix/prefix sebelumnya sebesar 0.111111. Secara ringkas dapat dilihat pada Persamaan 5 berikut.

Nilai Jumlah karakter suffix/prefix $=\sum_{i=1}^{\text {maks }} a$

Keterangan :

a : nilai variabel pada posisi $i$

max : jumlah maksimal variabel suatu suffix atau prefix

Cuplikan kode program untuk pemberian nilai suatu suffix/prefix dan nilai jumlah karakter suffix dan prefix dapat dilihat pada Gambar 6 dan Gambar 7.

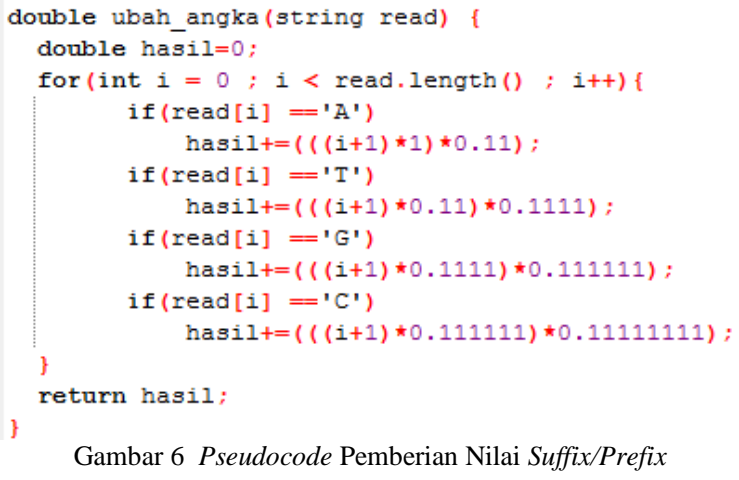

\section{Pencarian bagian overlap}

Setelah didapatkan nilai dari tiap prefix dan suffix menurut aturan pertama dan kedua, maka akan dilakukan proses pencarian overlap. Proses pencarian overlap dilakukan dengan membandingkan nilai dari masing-masing prefix dan suffix dari reads serta reverse complement satu sama lain.

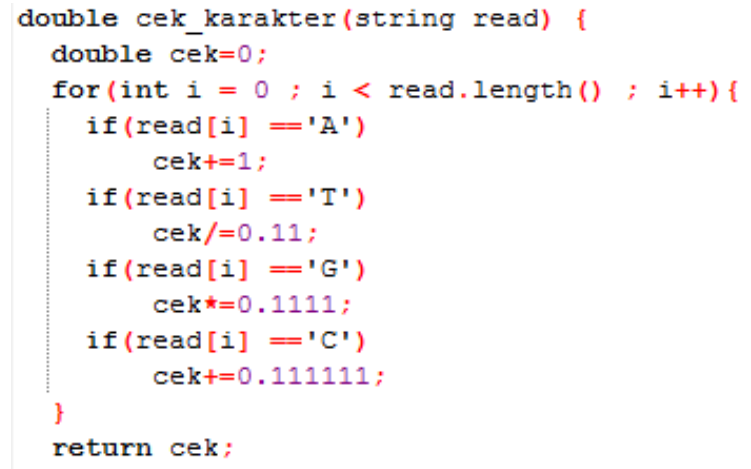

Gambar 7 Pseudocode Perhitungan Jumlah Karakter Suffix/Prefix

Proses perbandingan dilakukan dengan mengurangkan nilai dari masing-masing suffix yang ada dengan nilai dari masing-masing prefix yang ada. Suffix yang digunakan bukan hanya berasal dari bagian reads saja tetapi juga dari bagian reverse complement. Demikian juga prefix yang digunakan merupakan prefix dari bagian reads dan bagian reverse complement. Hal ini menyebabkan adanya 4 proses perbandingan yang dilakukan oleh sistem untuk menemukan bagian overlap dari masing- masing reads. Dalam hal ini, apabila nilai aturan pertama dan aturan kedua bernilai 0 maka reads/reverse complement dengan suffix tersebut memiliki overlap dengan reads/reverse complement dengan prefix yang bersangkutan. Untuk lebih jelasnya dapat dilihat pada Tabel 3.

Tabel 3 Proses Pencarian Overlap

\begin{tabular}{|c|c|}
\hline Jenis & Keterangan \\
\hline $\mathrm{S}$ reads - $\mathrm{P}$ reads & $\begin{array}{l}\text { Nilai suffix dari masing-masing } \\
\text { read dikurangkan dengan nilai } \\
\text { prefix dari masing-masing reads }\end{array}$ \\
\hline $\mathrm{S}$ reads - P RC & $\begin{array}{l}\text { Nilai suffix dari masing-masing } \\
\text { read dikurangkan dengan nilai } \\
\text { prefix dari masing-masing reverse } \\
\text { complement }\end{array}$ \\
\hline $\mathrm{S} \mathrm{RC}-\mathrm{P}$ reads & $\begin{array}{l}\text { Nilai suffix dari masing-masing } \\
\text { reverse complement dikurangkan } \\
\text { dengan nilai prefix dari masing- } \\
\text { masing reads }\end{array}$ \\
\hline S RC - P RC & $\begin{array}{l}\text { Nilai suffix dari masing-masing } \\
\text { reverse complement dikurangkan } \\
\text { dengan nilai prefix dari masing- } \\
\text { masing reverse complement }\end{array}$ \\
\hline
\end{tabular}

\section{Evaluasi jumlah node dan edge serta waktu eksekusi}

Pada tahap ini dilakukan proses evaluasi pada jumlah node dan edge yang dihasilkan oleh sistem serta waktu yang dibutuhkan untuk memprosesnya. Setelah semua reads (termasuk reverse complement) yang saling overlap telah terdata, maka dilakukan proses selanjutnya yaitu proses perhitungan node dan edge yang merupakan output dari sistem ini. Node merupakan perwakilan dari jumlah reads yang saling overlap satu sama lain sedangkan edge merupakan perwakilan dari jumlah overlap yang ada. Setelah proses pencarian overlap dilakukan maka setiap reads yang saling overlap dimasukan ke dalam suatu matriks yang mempunyai ukuran $\mathrm{n} \times \mathrm{n}$, di mana $\mathrm{n}$ adalah jumlah reads keseluruhan.

Pada sistem ini digunakan 2 matriks. Matriks pertama digunakan untuk menandai bagian overlap pada reads dan matriks kedua digunakan untuk menampung bagian overlap dari reverse komplemen. Pada matriks 1 , apabila reads i memiliki overlap dengan reads $\mathrm{j}$ maka matriks 1 baris i dan kolom j akan berisi nilai integer 1 . Apabila reads i overlap dengan reverse complement j maka matriks 1 baris i dan kolom j akan berisi nilai integer 1. Adapun apabila reads i memiliki overlap dengan reads $\mathrm{j}$ dan reverse complement $\mathrm{j}$ maka nilainya akan menjadi 3 . Hal yang sama juga diberlakukan pada matriks 2. Apabila reverse complement i memiliki overlap dengan reads j maka matriks 2 baris i dan kolom j akan berisi nilai integer 1. Apabila apabila reverse complement i memiliki overlap dengan reverse complement $\mathrm{j}$ maka matriks 2 baris i dan kolom j akan berisi nilai integer 1 . Adapun apabila reverse complement $\mathrm{i}$ memiliki overlap dengan reads $\mathrm{j}$ dan reverse complement $\mathrm{j}$ maka nilainya akan menjadi 3 . Setelah semua 
matriks terisi maka dicari jumlah node dan edge dari kedua matriks tersebut. Secara ringkas dapat dilihat pada Tabel 4.

Tabel 4 Matriks untuk Perhitungan Jumlah Node dan Edge

\begin{tabular}{|c|c|c|c|c|}
\hline Matriks & Baris i & Kolom j & overlap & Nilai \\
\hline \multirow[t]{6}{*}{ Matriks 1} & read $i$ & read j & $\mathrm{Ya}$ & 1 \\
\hline & read $i$ & reverse & Ya & 2 \\
\hline & & complement $j$ & & \\
\hline & read $i$ & read j dan & Ya & 3 \\
\hline & & reverse & & \\
\hline & & complement $j$ & & \\
\hline \multirow[t]{7}{*}{ Matriks 2} & reverse & read $j$ & Ya & 1 \\
\hline & complement $i$ & & & \\
\hline & reverse & reverse & Ya & 2 \\
\hline & complement $i$ & complement $j$ & & \\
\hline & reverse & read j dan & $\mathrm{Ya}$ & 3 \\
\hline & complement $i$ & $\begin{array}{l}\text { reverse } \\
\text { complement } j\end{array}$ & & \\
\hline & & complement J & & \\
\hline
\end{tabular}

Selain jumlah node dan edge, salah satu hal yang diperhatikan dalam penelitian ini adalah waktu eksekusi yang diperlukan oleh metode perbandingan nilai dan metode pencocokan string untuk jumlah input yang sama. Waktu eksekusi dihitung setelah user memasukan input berupa nilai panjang minimum overlap yang diinginkan. Waktu ekseskusi digunakan untuk membandingkan antara metode perbandingan nilai dan metode pencocokan string. Satuan waktu yang digunakan adalah detik (s).

\section{Spesifikasi Perangkat Lunak dan Perangkat Keras}

Perangkat lunak yang digunakan untuk mengembangkan sistem ini adalah Dev-C++ 5.4.1. Adapun perangkat keras yang digunakan untuk mengembangkan sistem ini adalah notebook bertipe Lenovo ThinkPad, CPU Intel Core i5-5200 2.20 $\mathrm{GHz}$ dengan memori $4 \mathrm{~GB}$.

\section{HASIL DAN PEMBAHASAN}

Pada penelitian ini panjang minimum overlap yang digunakan adalah 20, 25, dan 30 . Evaluasi dilakukan dengan melihat jumlah node dan edge serta waktu eksekusi yang dibutuhkan untuk mengkonstruksi overlap graph. Semakin sedikit node dan edge yang dihasilkan berarti overlap graph yang dihasilkan semakin sederhana. Semakin sedikit waktu yang dibutuhkan untuk mengkonstruksi overlap graph semakin efisien algoritme atau metode yang digunakan.

\section{Ketepatan hasil node dan edge}

Perbandingan hasil jumlah edge antara input 2000 reads dan 5000 reads dapat dilihat pada Gambar 8. Semakin besar nilai minimum overlap yang digunakan akan semakin sedikit jumlah edge yang dibentuk. Hal ini disebabkan parameter minimum overlap ini menunjukkan panjang substring yang sama antar dua reads. Dengan demikian, semakin kecil nilai minimum overlap, semakin kecil pula panjang substring pada reads, di mana menyebabkan semakin meningkatnya peluang ditemukannya substring yang sama (overlap) pada reads lainnya.

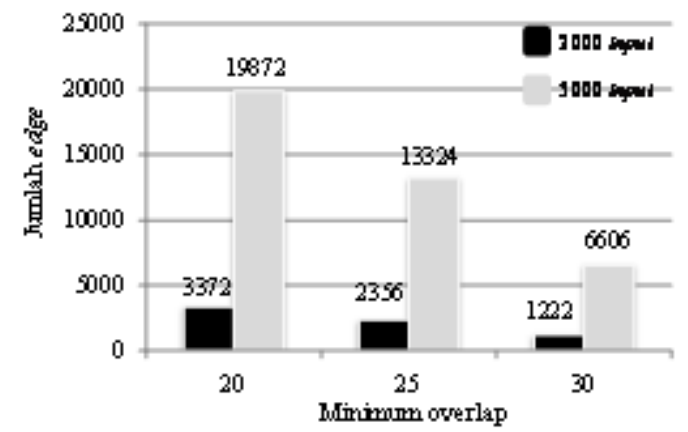

Gambar 8 Perbandingan Jumlah Edge untuk Input Jumlah Reads 2000 dan 5000

Hasil node dan edge yang dihasilkan pada penelitian ini dengan menggunakan metode perbandingan nilai dibandingkan dengan hasil node dan edge yang dihasilkan dengan metode konvensional (pencocokan string). Perbandingan dilakukan dengan jumlah reads 5000 dan 10000 dari dua sekuens DNA, yaitu dari Acidiphilium multivorum AIU301 plasmid pACMV4 dan Saccharomyces cerevisiae EC1118 chromosome V.

Tabel 5 menunjukkan perbandingan antara jumlah node dan edge dari metode perbandingan nilai dan metode pencocokan string dengan menggunakan sekuens DNA dari Acidiphilium multivorum AIU301 plasmid pACMV4. Dari hasil yang diperoleh, jumlah node dan edge yang dihasilkan dengan menggunakan metode perbandingan nilai sama persis dengan jumlah node dan edge yang dihasilkan dengan menggunakan metode pencocokan string untuk nilai minimum overlap 20, 25, dan 30 dengan jumlah reads 5000 dan 10000. Dengan demikian akurasi pembentukan node dan edge dari metode yang diusulkan dibandingkan dengan jumlah node dan edge yang dihasilkan dengan metode pencocokan string adalah sebesar $100 \%$

Adapun dengan menggunakan sekuens Saccharomyces cerevisiae EC1118 chromosome V, jumlah node dan edge yang dihasilkan oleh kedua metode hampir sebagian besar sama, hanya terdapat sedikit perbedaan, yaitu pada nilai minimum overlap 20 dan 25 untuk jumlah reads 10000. Perbedaan ini tidak signifikan, yaitu pada nilai overlap 20, terdapat selisih jumlah node sebesar $1(0.0023 \%)$ dan jumlah edge sebesar $5(0.091 \%)$. Adapun pada nilai overlap 25 hanya terdapat perbedaan jumlah edge dengan selisih $3(0.082 \%)$. Akurasi atau ketepatan jumlah node yang dihasilkan dengan menggunakan sekuens Saccharomyces cerevisiae EC1118 chromosome V adalah sebesar $99.9 \%$. Dari percobaan menggunakan dua sekuens DNA tersebut dapat dihitung akurasi rata-rata pembentukan node dan edge dengan menggunakan metode perbandingan nilai adalah sekitar $99.99 \%$. 
Hal ini menunjukkan bahwa metode yang diusulkan pada penelitian ini (perbandingan nilai) efektif untuk menghasilkan overlap graph. Kesamaan atau ketepatan dari sistem ini tak lepas dari nilai suatu overlap dan nilai jumlah karakter overlap yang digunakan. Nilai dari suatu overlap, prefix maupun suffix diharapkan mempunyai nilai yang unik, yaitu nilai suatu overlap dari suatu suffix atau prefix sama satu sama lain apabila suffix dan prefix tersebut mempunyai karakter yang terdiri atas basa-basa nitrogen dengan jumlah yang sama dan dengan urutan yang sama. Karena hasil suffix dan prefix yang dihasilkan dari reads dan reverse complement sangat banyak maka dapat menyebabkan ada beberapa nilai yang tidak unik, yaitu ada suffix atau prefix yang mempunyai nilai suatu overlap yang sama tetapi sebenarnya mempunyai karakter penyusun yang berbeda baik urutan maupun jumlahnya. Karena itulah digunakan nilai kedua. Nilai kedua(nilai jumlah karakter overlap) digunakan ketika sistem menemukan dua nilai suatu overlap yang sama. Jadi setiap suffix dan prefix dibandingkan dengan menggunakan 2 nilai dengan harapan bahwa hasil yang didapat maksimal. Untuk jumlah reads sebanyak 5000 dan 10000 buah, sistem dapat memberikan ketepatan sekitar $99.99 \%$ (Tabel 5-6).

Tabel 5 Jumlah Node dan Edge Menggunakan Sekuens Acidiphilium multivorum AIU301 Plasmid pACMV4

\begin{tabular}{|c|c|c|c|c|c|}
\hline \multicolumn{3}{|c|}{ Perbandingan nilai } & \multicolumn{3}{|c|}{ Pencocokan string } \\
\hline $\begin{array}{l}\text { Min. } \\
\text { overlap }\end{array}$ & $\begin{array}{l}\text { Jumlah } \\
\text { node }\end{array}$ & $\begin{array}{l}\text { Jumlah } \\
\text { edge }\end{array}$ & $\begin{array}{l}\text { Min. } \\
\text { overlap }\end{array}$ & $\begin{array}{l}\text { Jumlah } \\
\text { node }\end{array}$ & $\begin{array}{l}\text { Jumlah } \\
\text { edge }\end{array}$ \\
\hline \multicolumn{6}{|c|}{ Jumlah reads 5000} \\
\hline 20 & 4704 & 19872 & 20 & 4704 & 19872 \\
\hline 25 & 4436 & 13234 & 25 & 4436 & 13234 \\
\hline 30 & 3469 & 6606 & 30 & 3469 & 6606 \\
\hline \multicolumn{6}{|c|}{ Jumlah reads 10000} \\
\hline 20 & 4291 & 73896 & 20 & 4291 & 73896 \\
\hline 25 & 9232 & 49080 & 25 & 9232 & 49080 \\
\hline 30 & 8589 & 24270 & 30 & 8589 & 24270 \\
\hline
\end{tabular}

Tabel 6 Jumlah Node dan edge Menggunakan Sekuens Saccharomyces cerevisiae EC1118 Chromosome V

\begin{tabular}{|c|c|c|c|c|c|}
\hline \multicolumn{3}{|c|}{ Perbandingan nilai } & \multicolumn{3}{|c|}{ Pencocokan string } \\
\hline $\begin{array}{l}\text { Min. } \\
\text { overlap }\end{array}$ & $\begin{array}{l}\text { Jumlah } \\
\text { node }\end{array}$ & $\begin{array}{l}\text { Jumlah } \\
\text { edge }\end{array}$ & $\begin{array}{l}\text { Min. } \\
\text { overlap }\end{array}$ & $\begin{array}{l}\text { Jumlah } \\
\text { node }\end{array}$ & $\begin{array}{l}\text { Jumlah } \\
\text { edge }\end{array}$ \\
\hline \multicolumn{6}{|c|}{ Jumlah reads 5000} \\
\hline 20 & 1236 & 1466 & 20 & 1236 & 1466 \\
\hline 25 & 819 & 932 & 25 & 819 & 932 \\
\hline 30 & 422 & 446 & 30 & 422 & 446 \\
\hline \multicolumn{6}{|c|}{ Jumlah reads 10000} \\
\hline 20 & 4237 & 5488 & 20 & 4236 & 5483 \\
\hline 25 & 3088 & 3645 & 25 & 3088 & 3642 \\
\hline 30 & 1721 & 1872 & 30 & 1721 & 1872 \\
\hline
\end{tabular}

Dari Gambar 9 dapat dilihat perbedaan yang signifikan antara waktu eksekusi yang diperlukan antara kedua metode. Waktu eksekusi yang digunakan untuk metode perbandingan nilai secara keseluruhan jauh lebih cepat daripada waktu eksekusi metode pencocokan string. Bahkan dapat dilihat secara keseluruhan waktu yang digunakan metode pencocokan string 5 kali lipat lebih lama dari waktu eksekusi dengan metode perbandingan nilai.

Hal ini dapat terjadi karena metode proses perbandingan nilai menggunakan proses pengurangan sedangkan metode pencocokan string menggunakan proses penyamaan karakter dari masing-masing prefix dan suffix. Proses pengurangan membutuhkan waktu yang lebih cepat daripada proses penyamaan masing-masing string suffix-prefix.

Dengan demikian, penelitian ini memberikan hasil positif karena dapat membentuk bidirected overlap graph dengan waktu yang lebih cepat dan dengan ketepatan $99.99 \%$. Metode perbandingan nilai menghasilkan output lebih cepat dibandingkan dengan pencocokan string dikarenakan untuk membandingkan 2 buah string, komputer akan merubahnya dahulu menjadi nilai yang kemudian akan dibandingkan satu sama lain. Dengan metode perbandingan nilai, waktu yang diperlukan untuk mengubah string menjadi nilai dapat dihemat. Sistem ini mempunyai kompleksitas $\mathrm{O}\left(\mathrm{n}^{2}\right)$. Hal tersebut dikarenakan sistem menggunakan dua pengulangan dalam bentuk nested loop.

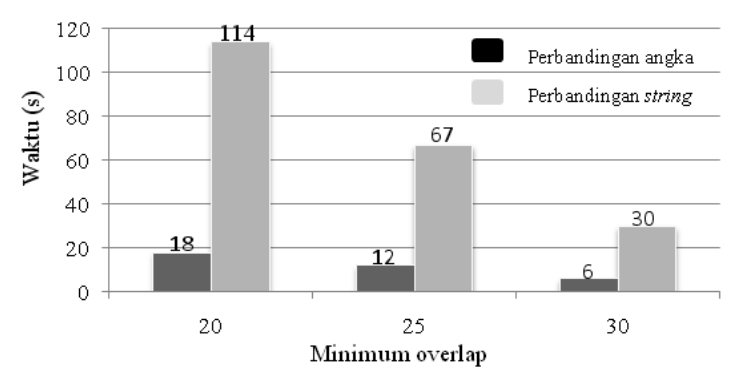

Gambar 9 Perbandingan Waktu Eksekusi Metode Perbandingan Nilai dan Pencocokan string untuk 5000 input reads

\section{Error Collision Rate}

Telah ditunjukkan pada pembahasan sebelumnya bahwa metode perbandingan nilai ini dapat menghasilkan ketepatan jumlah node dan edge yang saling overlap hingga $99.99 \%$. Namun demikian, dengan semakin banyaknya data input yang digunakan dapat menyebabkan suatu collision. Pada penelitian ini dicari error collision rate sebagai acuan sampai jumlah data input berapakah metode ini dapat digunakan dan tetap menghasilkan output dengan ketepatan yang tinggi.

Error collision rate ini dicari dengan membandingkan antara jumlah edge yang dihasilkan oleh metode perbandingan nilai dan jumlah edge yang dihasilkan oleh metode pencocokan string. Untuk itu dilakukan pengujian untuk mencari nilai ketepatan metode perbandingan nilai sampai dengan jumlah input / masukan 80000 reads dengan panjang setiap string yang dibandingkan satu sama lain memiliki panjang maksimum 34 bp dan panjang minimum adalah 30 bp. Hal ini dikarenakan untuk pengujian yang dilakukan digunakan panjang minimum overlap 30 bp. Jumlah input yang dimasukkan berjumlah 80000 buah. Namun setelah 
dilakukan penghilangan reads yang redundan, diperoleh reads sebanyak 69936 buah. Karena setiap reads akan memiliki suffix berjumlah 5 yaitu dengan panjang $34 \mathrm{bp}, 33 \mathrm{bp}, 32 \mathrm{bp}, 31 \mathrm{bp}$, dan 30 $\mathrm{bp}$, maka secara keseluruhan jumlah string dari reads berjumlah 349680 buah. Akan tetapi karena sistem juga memakai reverse complement yang memiliki jumlah yang sama dengan jumlah reads unik yang ada, maka jumlah string total yang dibandingkan satu sama lain berjumlah 699360 buah. Untuk jumlah masukan tersebut, metode perbandingan nilai menghasilkan jumlah edge yang sama persis dengan metode pencocokan string yaitu berjumlah 336414 buah. Sampai dengan jumlah input 80 000, metode perbandingan nilai memiliki nilai error collision rate $0 \%$, atau tidak ada collision, dengan menggunakan sekuens Acidiphilium multivorum AIU301 plasmid pACMV4. Dengan melihat hasil percobaan sebelumnya, dengan menggunakan sekuens yang berbeda, yaitu Saccharomyces cerevisiae EC1118 chromosome $\mathrm{V}$, kemungkinan diperoleh nilai error collision rate tidak lebih dari $1 \%$.

\section{KESIMPULAN}

Penelitian ini berhasil membentuk bidirected overlap graph dengan menggunakan teknik perbandingan nilai. Diperoleh informasi pula bahwa semakin kecil nilai overlap antar reads yang dipilih akan menyebabkan semakin lama waktu eksekusinya. Dari segi ketepatan jumlah node dan edge yang dihasilkan, metode perbandingan nilai memiliki akurasi sebesar $99.99 \%$ hampir sama dengan menggunakan metode pencocokan string. Adapun dari segi waktu eksekusi, metode perbandingan nilai lebih efisien dibandingkan dengan pencocokan string, yaitu lima kali lebih cepat. Dengan demikian, metode perbandingan nilai cukup efektif dan efisien untuk digunakan sebagai alternatif teknik dalam pembentukan bidirected overlap graph.

\section{DAFTAR PUSTAKA}

ABEGUNDE, T., 2010. Comparison of DNA sequence assembly algorithms using mixed data sources [tesis]. Saskatoon (CA): University of Saskatchewan.

BANKEVICH, A. et. al. 2012. SPAdes: a new genome assembly and its application to single cell sequencing. Journal of Computational Biology, vol 19, no. 5, pp 455-477

BATZOUDLOU, S., JAFFE, D.B., STANLEY, K. et. al., 2002. ARACHNE: A whole genome shotgun assembler. Genome Res. 12: 177189

BOZA, V., Brejova, B., Vinar, T. 2014. GAML: genome assembly by maximum likelihood.
Algorithm in Bioinformatics, Lecture Notes Bioinformatics, 8701, pp 122-134.

BRENNER, S., JOHNSON, M., BRIDGHAM, J., GOLDA, G., LLOYD D.H., JOHNSON, D., LUO, S.J., McCURDY, S., FOY, M., EWAN, M., et al., 2000. Gene expression analysis by massively parallel signature sequencing (MPPS) on microbead arrays. Nat Biotechnol. 18:630-634.

CHAISSON, M., PEVZNER, P., TANG, H.. 2004. Fragment assembly with short reads. Bioinformatics. 20(13):2067-2074.

COMMINS, J., TOFT, C., FARES, M.A., 2009. Computational Biology Methods and Their Application to the Comparative Genomics of Endocellular Symbiotic Bacteria of Insects. Biol Proced Online. 11:52-78. doi: 10.1007/s12575-009-9004-1.

HERNANDEZ, D., FRANCOIS, P., FARINELLIi, Østerås M., SCHRENZEL, J., 2008. De novo bacterial genome sequencing: Millions of very short reads assembled on a desktop computer. Genome Res. 18:802809

HUANG, X., WANG, J., ALURU, S., YANG, S., HILLIER, D., 2003. PCAP: A wholegenome assembly program. Genome Res. 13: $2164-2170$

KAE, H. 2003. Genome Project: uncovering the blueprints of biology. The Science Creative Quarterly.

KUSUMA, W.A., ISHIDA, T., AKIYAMA, Y., 2011. A combined approach for de novo DNA sequence assembly of very short reads. IPSJ Transaction on Bioinformatics. 3(10):21-33. doi: 10.2197/ipsjtbio.4.21.

MANBER, U., MYERS, E.W., 1993. Suffix arrays: a new method for on-line string searches. SICOMP. 22(5):935-948.

MEDVEDEV, P. et. al. 2007. Computability of Models for Sequence Assembly. Algorithms in Bioinformatics, Lecture Notes in Computer Science, vol. 4645, pages 289-301.

MULliKIN, J.C., NING, Z., 2003. The Phusion assembler. Genome Res. 13:81-90

MYERS, E.W., SUTTON, G.G., DELCHER, A.L., et. al., 2000. A whole-genome assembly of Drosophila. Science. 287: 2196-2204

POP, M., 2009. Genome assembly reborn: recent computational challenges. Briefing in Bioinformatics. 3(7):47-54

RICHTER, D.C., OTT, F., AUCH, A.F., SCHMID, R., HUSON, D.H., 2008. Metasim-A sequencing simulator for genomics and metagenomics. PLoS ONE. 3(10): e3373 
416 Jurnal Teknologi Informasi dan Ilmu Komputer (JTIIK), Vol. 7, No. 2, April 2020, hlm. 407-416

SIMPSON, J. T. and POP, M. 2015. The Thory and Practice of Genome Sequence Assembly. Annu. Rev. Genomics Hum. Genet. 2015. 16:153-72

ZHOU, X., REN, L., MENG, Q., LI, Y. YU, Y., YU, J., 2010. The next-generation sequencing techmology and application. Protein Cell. 1(6): 520-536 